\title{
Addressing the Question of Homophobia in Jordanian Public Discourse
}

\author{
Ahmad El-Sharif \\ Department of English Language and Literature, Al-alBayt University, 25113, P.O. Box 130200, Mafraq, Jordan \\ E-mail: a.el-sharif@aabu.edu.jo
}

Received: 27-06-2016

Accepted: 30-08-2016

Published: 02-01-2017 doi:10.7575/aiac.ijalel.v.6n.1p.47

Advance Access Published: November 2016

URL: http://dx.doi.org/10.7575/aiac.ijalel.v.6n.1p.47

\begin{abstract}
This article investigates the question of homosexuality, homosexuals, and homophobia in the Jordanian public debate in the aftermath of an LGBTQIA meeting that was held secretly in Amman in May 2015. The main purpose of the article is to demonstrate the constituents and arguments which reproduce the public discourse on anti-homosexuality and antihomosexuals and homophobia in Jordan. This purpose is reached by analysing 35 journal articles written in Standard Arabic in Jordanian public and open-access media. The analysis involves the qualitative analysis of the argument, processes, and themes used to represent homosexuality and homosexuals by the discourse producers. The analysis reveals that the question of homosexuality and homosexuals in Jordan can be addressed in terms of seven angles: the public anti-homosexuality and anti-homosexuals' calls, the (Islamic) religious argument, protecting and reinforcing law and order, the argument of (homo)sexually-transmitted diseases, the calls of pro-homosexuality and pro-homosexuals and LGBTQIA's rights activists, the homosexuals' own self-representation, and the neutral scientific account and representation.
\end{abstract}

Keywords: Jordan, homosexuality, homosexuals, homophobia, LGBTQIA, discourse analysis

\section{Introduction}

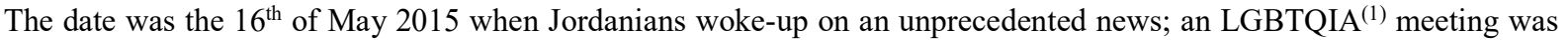
privately held in Amman, and its outcomes were announced publicly by media. The announced meeting involved about 40 people and organized by the on-line My.Kali Magazine and some anonymous LGBTQIA activists advocating the LGBTQIA rights. The meeting took place in an undisclosed venue in central Amman to mark the International Day Against Homophobia, Transphobia and Biphobia. According to the organisers, the participants were "a small crowd full of hope for a better and safer future for the LGBTI community in Jordan", and they got together to "raise awareness of the social and economic challenges facing the LGBTQIA community". In the aftermath of the event, the details of the meeting found their way to Jordanian public media; especially when My.Kali Magazine indiscreetly published an article celebrating the meeting with names, photographs, and event agenda. The organisers and attendance addressed what they considered as the problem of homophobia in Jordan, and they shared viewpoints on the main challenges which LGBTQIA members face in Jordan. Among the participants was a local lawyer and activist on civil rights who explained to the attendants the legal status of gay, lesbian, and transgender communities in the middle-eastern Kingdom. Such status is found to be conflicting with several challenges which LGBTQIA members claim to be facing; such as social and legal recognition, challenges of transgender individuals, challenges of LGBTQIA business owners, and challenges of heterosexual members in the society who support the LGBTQIA community's cause. At the end of the event, the organizers and participants dubbed the event 'Squeezing Identity Out of the Box', and they decided to announce plans to take more actions on the ground to obtain the official recognition of their status in Jordan.

Remarkably, the highlight of the event was the unprecedented attendance of Western diplomats in Jordan, materialised by the U.S Ambassador in Jordan, Her Excellency Alice G. Wells, who paid the organisers and the participants an unexpected, though publicly condemned, visit. What is more, she conveyed to the audience her support for the meeting's cause and shared with them her personal experiences by quoting the US former Secretary of State Hillary Clinton's stance at the UN in 2011 that "gay rights are human rights and human rights are gay rights" (for a full account of the speech, see Weiner, 2013). The Jordanian public opinion did not underestimate the event and its outcomes; especially Ambassador Well's appearance, who has been repeatedly attacked in the media since her appointment in 2014. This act was interpreted as an attempt to force LGBTQIA equality in Jordan, and it is understood by Jordanian as interference in the local affairs of the Jordanian society, and a breach of the nation's sovereignty. Furthermore, the Jordanian public opinion, who condemned the event and its organisers, did not hesitate in showing concern that such activities could pave the way towards reaching a public dialogue and a common language in which the LGBTQIA community in Jordan can challenge the societal beliefs and norms which would lead towards having a safe harbour for them in Jordan. 
Despite the fact that the number of the participants in the event was described by its organisers as "a small crowd" and it is not the first gathering of members of LGBTQIA in a private event (and within the trusted-circle), but the public outcry was bigger than any time before. The public opinion was mobilised by concerns of a future where LGBTQIA people are recognized as a component of the Jordanian society, a provision which motivates the flux of societal, religious, and cultural conflicts and brawls which could threaten the social stability of the Kingdom. Herein, the event was widely discussed by both private and public newspapers, splashed on many on the newspapers front pages, talked about on private television and radio stations, and was even pointed to by few members of the Parliament. Herein, Jordanian media and several public figures, especially those of moderate and fundamentalist religious orientation (Islamic and Christian), have steered the public opinion in condemning the meeting, its organisers, Ambassador Wells' attendance, and more ardently, the absence of any official reaction against the event and its organisers. For instance, the Jordanian daily newspaper Al-Ghad reported that a Jordanian lawyer had announced that he filed a complaint against Ambassador Wells. The ground of the complaint, according to the lawyer, is that Wells' attendance was "a breach of public order and the constitution, by setting up a meeting to demand the rights of gays and homosexuals in the presence of US Ambassador to Jordan."

This article investigates and analyses the discursive representations of the communal mainstream that denounces homosexuality and homosexuals, as identified, in Jordanian public discourse. The analysis is conducted on the basis of the systematic categorization of the news reports and articles on LGBTQIA community published in Jordanian medias in the aftermath of the reports of the inauguration of a meeting for homosexuals in Amman on 16 May 2015, and with the presence the US Ambassador in Amman. As the organisers signalled in this event the start of their most 'courageous' campaign to promote the 'rights' of LGBTQIA in Jordan and to "Squeezing Identity Out of the Box" and "raise awareness of the social and economic challenges facing the LGBT community", this step was met by a wave of public condemnation which has circulated in media for the following weeks in the form of a public discourse that varies in its regard to the question of homophobia in Jordan, and the manner in which it is addressed.

\section{Setting and Objectives}

As it is acknowledged, the aforementioned meeting was not the first LGBTQIA activity to be organised in Amman, such activities were understood to be organised within the members of the LGBTQIA 'trusted and close circle'. Participants in these activities would only nominate trusted friends through the organising body and who would notify them with the details of the activities by e-mails or social media with a warning message that such activities, or meetings, are a "low-profile" event. Nevertheless, the meeting signalled the first time the issue of the 'rights' of homosexuals in Jordan to be publicly raised and under patronage of influential figures such as Ambassador Wells. Remarkably, the event coincided also with the Irish historic 'Yes' vote for same-sex marriage on 22 May 2015 (See Johnston, 2015).

The event is understood to be called for and organised by a webzine named My.Kali; an online social outlet that publishes in English and is started from Jordan in $2007^{(2)}$. My. Kali says that it is established by a group of "passionate students with various interests ranging from design, to the arts, and politics". As the $1^{\text {st }}$ LGBTQIA publication to ever exist in the MENA region, and in order to absorb the immense stir and controversy the webzine caused at the time as a gay-themed publication, My.Kali has regularly featured non-LGBTQIA artists on their covers to encourage acceptance among other communities. Later, it began to promptly addressing homophobia and transphobia and focusing on the LGBTQIA affairs in the Jordanian society such as their ideas, demands, and activities in order to empower their youth "to defy mainstream gender binaries in the Arab world" as it is plainly stated in their website. For this reason, My.Kali proved its advocacy to LGBTQIA community in Jordan by celebrating the International Day against Homophobia and Transphobia (IDAHOT). This celebration, though not public, has immensely alerted the Jordanian public opinion about the existence of a small, though organised, LGBTQIA community in Jordan. Several recent local and international reports suggested that Jordan involves a relatively large LGBTQIA community who live in the closet and lead double lives. The flux of social networks and the unrestrained access to internet in Jordan have encouraged members of this community, especially younger LGBTQIA, to begin coming out of the closet and becoming more visible. Some reports argue that LGBTQIA in Jordan is making now a vibrant community of young professionals, journalists, writers, artists and filmmakers. Jordanian media, on the other hand, evocatively link those young Jordanians to the 'spoiled-youth' of the 'liberal' wealthy families who are enjoying their life of celibacy.

In the following days of the event, online (mostly private) media outlets in Jordan have predominantly focused on the event in a way that is undesirable to the event organisers. Almost all media outlets attacked the event and its organisers claiming that its aim is no less than a gathering of LGBTQIA people to celebrate their homosexuality and demanding 'rights' in a conservative society that forbids homosexuality and any sexual relationship outside the institution of heterosexual marriage. Some websites, and public figures, have hinted to the US Ambassador's suspicious appearance in the event, and accused her to be the actual organizer and promoter for the infamous gathering. In addition, the readers' reaction as listed in most these articles demonstrated a massive attack that shows their refusal and abomination towards the event, its organisers, and its attendants. In many instances, it was easily noticeable from the writers and readers' reaction that the Jordanian public opinion is homophobic and transphobic and charged against LGBTQIA community and its members to the extent that they did not seem to recognise categories of homosexuals and to admit the distinction between a gay and a transgender.

Jordan prides itself as a state of social and religious freedom; thus, one can easily notice that there is a growing level of tolerance and visibility among the different strata of society especially within the artistic or chic-cosmopolitan parts of 
Amman and some other major cities. However, this social tolerance and cohabitation is not easily perceivable within the realm of LGBTQIA rights. Jordan does not recognise LGBTQIA as a minority like religious and ethnic minorities in the Kingdom. In this regard, one can argue that the LGBTQIA community in Jordan undergoes social biases and conventions like that exist within the gay community in Europe and the United States. In a conservative middle-eastern society that values masculinity and heterosexual institutionalised marriage, any aspect of same-sex marriages or civil unions are deemed illegal. However, a revision of the Jordanian Criminal Code proposed in 1951 implicitly legalized consensual sodomy; with the age of consent set at 16 years and under the condition that the act is done in private, by adult, and for non-commercial purpose (Schmitt and Jehoeda, 1992: 137-138). Since then, and for social and religious reasons, the Jordanian Parliament would never adopt legislation that addresses what is considered as sexual identitybased discrimination or anti-discrimination law that prohibits discrimination on the grounds of sexual orientation. Moreover, at the Fourth World Conference on Women held in 1995, Jordanian government made a public statement regarding LGBTQIA rights, and its delegates to the conference helped, with other delegates, on redressing a proposal to have the conference formally addresses the 'human' rights of gay and bisexual women. In another recent occasion, Jordan delegates to the United Nations (UN) have opposed another UN proposal to have the United Nations itself supports LGBTQIA rights; however, the UN eventually adopted the proposal.

\section{Situating a Discourse}

Jordan has endorsed various international conventions which prohibit discrimination against minorities. Despite the fact that the discrimination on the basis of sexual orientation has never been of particular concern to any international convention or treaty, the United Nations Human Rights Committee affirms that Articles 2 and 26 of The International Covenant on Civil and Political Rights tacitly includes the individuals' sexual orientation and gender identity as grounds of discrimination (UN Human Rights Committee, 1994). Nevertheless, in Jordan, and most Arabic countries, an individual's sexual orientation is not recognised as a ground of discrimination. This status represents a serious challenge to LGBTQIA communities and their activities, and it constantly raises the question about the relationship between homophobia in the Arab world and the social and religious culture, largely dominated by conservative ideas that value righteousness and manhood and abominate abnormal deviancy and indecency. By homophobia, I refer here the term coined by the American psychologist George Weinberg and defined as 'the dread of being in close quarters

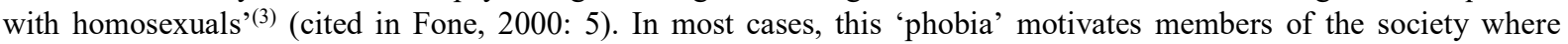
LGBTQIA activities are publicly announced to resort to irrational prejudices obsessed with the beliefs that the LGBTQIA communities are enemies and conspirators who work as members of organised-crime groups. Consequently, members of LGBTQIA are perceived inferior and unwelcomed in society because they are not normal heterosexual citizens like the rest. In addition, LGBTQIA members are depicted as narcissists and sexually threatening to normal heterosexual members of the society.

The observers of Jordanian media and public discourse in the aftermath of the LGBTQIA meeting in Amman can easily perceive how people of non-heterosexual orientation are portrayed and referred to in a manner reflects a lack of understanding of the nature of homosexuality, and at certain level, the basic principles of human rights as well. Both public and media discourses have prodigiously concentrated on the severity of organising the meeting in a conservative society. Meanwhile, the anti-homosexuals discourse mainstream in the following days of the meeting disseminates the discrimination of the LGBTQIA person and those who anonymously defended their rights in organising the meeting or any other activities on the ground of civil and human rights which the constitution protects. The outcry exceeds condemning the meeting and its organisers to convict homosexuality as behaviour. In this regard, a homosexual conduct is described as a serious disease, commonly compared to obscenity and indecency (faHesha), and thus described as absolutely incompatible with the dominant Islamic religious identity and the culture of society. In such a socio-cultural environment, the LGBTQIA community in Jordan experiences continuous verbal pressures and bouts by society. However, since the LGBTQIA meetings and activities were always organised at undisclosed venues, no incident of physical outbreaks of violence against them ever recorded. In this regard, one may argue that the status of LGBTQIA community can be discursively recognised by the LGBTQIA as that of a minority that is subject to intangible verbal discrimination and marginalisation by the Jordanian public opinion and media in their anti-homosexuality and antihomosexuals and homophobic discourse.

Hence, this article sheds light on the socio-cultural motivations for anti-homosexuals and homophobic attitudes in Jordanian society. The main goal of the article is to address the different arguments around homosexuality and paying most attention to the discourses manifested through the verbal, and not physical, attacks on LGBTQIA and their ideas, demands, and activities. This aims to shed light on the question of anti-homosexuality and anti-homosexuals and homophobia as addressed by the Jordanian public and media discourse. This article proposes that anti-homosexuality and anti-homosexuals and homophobia public discourse in Jordan is motivated by the (Islamic) religious ideology and the deeply-rooted socio-cultural beliefs and some folk ideas which all together formulate a unified and comprehensive ideology that aims to marginalise and criminalise LGBTQIA community in Jordan. This discourse is not independent from power relations and its distribution in society where the heterosexual majority imposes its ideologies and beliefs on the homosexual minority. Herein, critical discourse analysis is used here as the main methodological and analytical approach by which the article associates particular importance to the distribution of power through language between the different arguments and actors who stimulated the debate about the LGBTQIA meeting and their events and demands. In addition, the analysis will reveal how language is used to legitimise discrimination against LGBTQIA community, as a minority, and its practices and activities and the way they are marginalised by society. 
As indicated above, the present article studies the discourse of anti-homosexuality and anti-homosexuals and homophobia in Jordanian society as reproduced in public debates. The article here relies on the connotation of the notion of 'discourse' within the realm of critical social theory and post-structuralism. This allows us to comprehend a 'Discourse', as Burr (1995:48) states:

[a] set of meanings, metaphors, representations, images, stories, statements and so on that in some way together produce a particular version of events.... surrounding any one object, event, person etc., there may be a variety of different discourses, each with a different story to tell about the world, a different way of representing the world.

Such posture is consolidated through the proposition that what people talk about in public (e.g. shopping, drugs, the royal family, etc.) would be drawn from their community's repertoire of things possible to say in that community rather than representing some unique perspective on the topic under debate (Cameron, 2001: 15). Still, these repertoires and perspective are not necessarily subject of one discourse, but many 'discourses' (ibid.) and which in turn may be interrelated in their support or oppose of each other. What is more important here is the fact that such 'same-mind' discourses, or opposing ones, may anticipate and predict impending social change (Pecheux, 1982). For the topic in hand, we propose that a set of socio-cultural, religious, and political arguments may have raised to the surface concerning the question of anti-homosexuality and its adverse pro-sexuality (of LGBTQIA) discourses in Jordan. These arguments have worked on reviving the society's awareness of the existence of the LGBTQIA as an organised group; thus, the Jordanian public admits that the LGBTQIA's affaires and their meetings do not make new themes. In the aftermath of the meeting, few pro-homosexuals anonymously argued that homosexuality in Jordan has existed long before the meeting (Magid, 2014). Accordingly, anti-homosexuality and anti-homosexuals and homophobic discourse in Jordan is not the product and the result of the denounced meeting; instead, it is a metamorphosis; a transformation in the public, which was mostly provoked by Wells' attendance and the raising voices of those who defend the civil rights of homosexuals in Jordan. These voices support Jordanian homosexuals to disclose their strong affiliations towards their social and sexual identities, relationships, and activities. The same voices may call later for a new set of social transformations through which LGBTQIA members could gain some civil rights; like performing officially-accredited civil partnership contracts. Then, the ultimate goal of LGBTQIA and pro-homosexuality debate would be to construct a discourse of a new gender-identity category and under which Jordanian homosexuals can be officially categorised. On the other hand, the anti-homosexuality debate aims to construct a discourse that consolidates the conservative identity of society, and to prevent the circulation of any discourse that seeks the accreditation and acceptance of LGBTQIA members as a minority group in society.

A central argument of the anti-homosexuality and anti-homosexuals rally against LGBTQIA community in Jordan is that the former commercialises the later as a product of the Western cultural and its liberality and 'permissiveness'; for instance, adopting the US Ambassadors' defence of the LGBTQIA rights in Jordan and here presence in the meeting. The LGBTQIA community does not opt to create a form a discourse about homosexuality that is culturally appropriate; this stance makes the LGBTQIA the problem rather than homosexuality. In his book Desiring Arabs, Joseph Massad sees that that LGBTQIA groups in the Arab world are engaging in what Foucault calls 'incitement to discourse' (Massad, 2007: 37) in order to enforce Western norms and conventions concerning sexuality, and homosexuality, on the Arab world. Their aim, according to Massad, is to trigger epistemic violence that will let the West to better subjugate the Arab World. This perspective, among several other ones, constructs one aspect of reality of theme of homosexuality and homophobia in Jordanian society that is discursively structured. Accordingly, studying anti-homosexuality and antihomosexuals and homophobia language in Jordan will help in shaping our understanding of the Jordanian socio-cultural context. Besides, this language embodies the 'material objects and social practice' which exist, but discursively formed, outside of language (Barker, 2003: 102).

The current article aims to show how public media has presented the question of homosexuality and homophobia in Jordan by means of public debates in media outlets. The result was the production of new category of Jordanian citizens: the LGBTQIA. Those people have existed before the announcement of their meeting, and they have had their own private events and activities as before, but the Discourse formulated in the aftermath of the meeting is believed to construct a new identity category, or a minority group, in Jordan. This new identity category, or minority, will demand specific rights, will oblige for responsibilities, and will attain acknowledged status. As it is widely acknowledged in the field that there is not just one discourse of a particular subject, but many 'discourses' (Cameron, 2001: 15), this article deals with contesting, or contradictory, discourses of homophobia and anti-homosexuality and pro-homosexuality discourses in Jordan simultaneously. This account would provide insights and indicators of possible forthcoming social change (Pecheux, 1982) as the public awareness of the existence of an LGBTQIA community in Jordan is in the process of being raised.

\section{Findings and Argument}

This article aims to situate homosexuality in Jordan within the context of the anti-homosexuality and anti-homosexuals and homophobia debates in public discourse. The question this articles addresses is "What are the constituents and arguments which reproduce the public discourse on anti-homosexuality and anti-homosexuals and homophobia in Jordan?'

The data of this article is collected from Jordanian media which have tackled the affaires of the LGBTQIA meeting on the $16^{\text {th }}$ of May 2015. The data is in written form, and it covers the period of one month after the meeting. This short period was blatantly characterized by intensified public and socio-political debate about the meeting and its organisers, 
attendants, and themes. Relying on media to represent the public debate was deliberate and purposeful since they promote 'social, economic and political philosophies...[i]t is powerful and influential, and colours and infuses the character, ideals and institutions of the individual, the family and the community' (Harris and Johnson, 1977:174). In addition, relying on media to reflect public debate and discourse aims to represent the circulated sets of interrelated lexical, phraseological and grammatical linguistic representations in the discourse which could characterize the discourse in hand. These representations constitute part of these means which each party (anti-homosexuals and prohomosexuality) aims to significantly exploit to influence the public opinion. Accordingly, and following critical approaches to discourse analysis, the goal is to analyse such representations of homosexuality and LGBTQIA community in Jordan.

The data in hand consists of a collection of 35 journal articles written in Standard Arabic in Jordanian public and openaccess media; such as daily newspapers and online journals. The writers of these articles are Jordanian public figures of socio-political and religious affiliations, but they are not necessarily specialised full-time columnists.

The Analysis involves the identification of all representations of ant-homosexuality and anti-homosexuals and LGBTQIA community in the articles. Then, contextual qualitative analysis is performed with the aim is to accentuate a set of arguments deduced from these representations. Following that, the article then illustrates a categorization of these arguments which characterise the pro-homosexuality, anti-homosexuality, and homophobia discourse in Jordan. This categorization is discussed with supporting examples of lexes (words and phrases) extracted from representative texts. These defined arguments are built on identifying the ideational meaning of the immediate context where stances and standpoints are verbally presented according to the predefined arguments and themes. So, these contexts can make words, phrases, and simple sentences which involve lexes with envisioned connotations. The linguistic analysis reveals the function of lexical choice in representing 'processes' or 'experiences': actions, events, processes of consciousness and relations' (Halliday, 1985: 53). Herein, our concern is oriented towards the processes and the themes in the antihomosexuality and homophobia discourses first and that of pro-homosexuality later. Such analysis reflects the cultural and ideological conceptualisation and representation of the themes and arguments of each party and its allies.

The qualitative analysis of the discourse on anti-homosexuals and anti-homosexuality and homophobia in Jordan revealed that there is a conformist argument in Jordanian public discourse that regards the question of homosexuality a prohibited area of official discussion by the government. Few governmental bodies, as we will present below, have addressed the question of homosexuality in Jordan. This stance resulted in a very serious problem regarding the identification of homosexuality and homosexuals and the way they must be 'officially' labelled. For instance, the data in hand reveals that the Jordanian public tends to refer to homosexuals as almethleyeen and gays as al-shathawaath gensian (the sexually perverts) in their public writing, but not in their everyday slang. Thus, the two terms almethleyeen and al-shathawaath gensian are used interchangeably by the discourse producers, and ones translated, the terms 'homosexual' and 'gay' are used interchangeability without any reference to the connotation of each term as they both refer to shaath (singular of 'pervert'). In fact, few public figures and intellectuals in Jordan warned against this proposition and emphasised that homosexuality and its different categories should be studied scientifically using systematic and recognised terminologies.

Leaving the aforementioned problem to another study, this article addresses the way homosexuality and homosexuals (or gays) are expressed in Jordanian public discourse. The analysis reveals that this issue can be approached on the basis of seven angles: the public anti-homosexuality and anti-homosexuals' calls, the (Islamic) religious argument, protecting and reinforcing law and order, the argument of (homo)sexually-transmitted diseases, the calls of pro-homosexuality and pro-homosexuals and LGBTQIA's rights activists, the homosexuals' own self-representation, and the neutral scientific account and representation. These angles were thoroughly and discursively studied by looking to the lexical choice of the discourse producers and the processes involved in addressing the themes in accordance with the provisioned angles. In this regard, our main emphasis is oriented towards the discourse producers, the way they perceive homosexuality, the way they perceive homosexuals and gays, who should handle the issue according to the angle perceived, what to be done, and what goals are expected.

\subsection{The Public Anti-Homosexuality and Anti-Homosexuals Calls}

The collected data reveals that the Jordanian public discourse is persistently unified on rejecting and condemning homosexuality and its committers in Jordan. The announced meeting and the attendance of the US Ambassador is considered the alarm bell of the existence of an organised LGBTQIA community who organise their events under patronage of foreign embassies but, as it sounds, behind the back of the Jordanian authorities. These calls were propagated by many Jordanians who collectively formulate the discourse in hand, and this discourse is characterised by its multifaceted arguments and propositions with regard the processes and actions associated with the antihomosexuality and anti-homosexuals discourse, and this is represented in Table 1 below $^{(4)}$ : 
Table 1. Representative examples of the lexical choice of the processes and themes with regard of antihomosexuality and anti-homosexuals discourse in Jordan

\begin{tabular}{|c|c|c|c|c|c|c|c|c|c|}
\hline $\begin{array}{l}\text { Discourse } \\
\text { Producers }\end{array}$ & & homosexuality is.... & & $\begin{array}{c}\text { a homosexual } \\
\text { is.... }\end{array}$ & & $\begin{array}{c}\text { who must } \\
\text { act... }\end{array}$ & $\begin{array}{c}\text { what must it } \\
\text { do...? }\end{array}$ & & the purpose \\
\hline $\begin{array}{l}\text { the General Ifta'a } \\
\text { Department (a } \\
\text { governmental } \\
\text { institution) }\end{array}$ & 0 & $\begin{array}{l}\text { the act } \\
\text { (illegitimate son) }\end{array}$ & & & 0 & $\begin{array}{l}\text { the relevant } \\
\text { authorities }\end{array}$ & $\begin{array}{l}\text { to nip in } \\
\text { the bud } \\
\text { (lit. to } \\
\text { burry a } \\
\text { new-bon } \\
\text { enfant in } \\
\text { a grave1) } \\
\text { this act, } \\
\text { and do } \\
\text { not } \\
\text { spread in } \\
\text { the } \\
\text { commun } \\
\text { ity }\end{array}$ & & \\
\hline $\begin{array}{l}\text { Islamic Action } \\
\text { Font }\end{array}$ & & & $\circ$ & $\begin{array}{l}\text { corrupted } \\
\text { models } \\
\text { advocates of } \\
\text { vice and } \\
\text { obscenity }\end{array}$ & o & $\begin{array}{l}\text { security } \\
\text { services }\end{array}$ & $\begin{array}{l}\text { dealing it } \\
\text { with the } \\
\text { utmost } \\
\text { firmness } \\
\text { and } \\
\text { strength }\end{array}$ & ○ & $\begin{array}{l}\text { maintaining } \\
\text { our ethics, } \\
\text { our values } \\
\text { and } \\
\text { authentic, } \\
\text { and social } \\
\text { traditions }\end{array}$ \\
\hline $\begin{array}{l}\text { Jordan Islamic } \\
\text { Scholars League }\end{array}$ & & & $\circ$ & $\begin{array}{l}\text { suspicious } \\
\text { meeting }\end{array}$ & o & $\begin{array}{l}\text { to put us } \\
\text { before our } \\
\text { responsibili } \\
\text { ties }\end{array}$ & & ○ & $\begin{array}{l}\text { the defence } \\
\text { of the great } \\
\text { achievement } \\
\text { s and } \\
\text { precious } \\
\text { values }\end{array}$ \\
\hline M.R (an MP) & ○ & $\begin{array}{l}\text { a stab to Amman } \\
\text { Islamic Message }\end{array}$ & $\circ$ & $\begin{array}{l}\text { the so-called } \\
\text { (gays and } \\
\text { people of }\end{array}$ & & & & $\circ$ & $\begin{array}{l}\text { Amman } \\
\text { moderate } \\
\text { Islamic }\end{array}$ \\
\hline & ○ & $\begin{array}{l}\text { a provocation to } \\
\text { the feelings of } \\
\text { Jordanians and } \\
\text { Ammanis }\end{array}$ & 0 & $\begin{array}{l}\text { sexual } \\
\text { perversion) } \\
\text { breakers of } \\
\text { tradition and } \\
\text { law }\end{array}$ & & & & & $\begin{array}{l}\text { Message } \\
\text { that calls for } \\
\text { the virtues } \\
\text { and respect } \\
\text { the } \\
\text { humanity of } \\
\text { mankind }\end{array}$ \\
\hline $\begin{array}{l}\text { O. Sh. (Islamic } \\
\text { preacher and } \\
\text { researcher) }\end{array}$ & $\circ$ & $\begin{array}{l}\text { serious violations } \\
\text { of the right of } \\
\text { almighty god and } \\
\text { his law and } \\
\text { believers } \\
\text { deviation } \\
\text { (homosexuality) } \\
\text { serious indicators }\end{array}$ & & & & & & ○ & $\begin{array}{l}\text { threatens the } \\
\text { security of } \\
\text { the country } \\
\text { and its } \\
\text { people }\end{array}$ \\
\hline $\begin{array}{l}\text { Dr. I. S } \\
\text { (newspaper } \\
\text { columnist) } \\
\text { O. K. (newspaper } \\
\text { columnist) }\end{array}$ & o & $\begin{array}{l}\text { it does not see in } \\
\text { sexual perversion } \\
\text { a sound behaviour } \\
\text { to diverge our } \\
\text { youth toward } \\
\text { deviation } \\
\text { (homosexuality) } \\
\text { and exotic ideas, } \\
\text { both intellectual } \\
\text { and behavioural. }\end{array}$ & O & $\begin{array}{l}\text { suspicious } \\
\text { organisation }\end{array}$ & & & & ○ & $\begin{array}{l}\text { gain support } \\
\text { of western } \\
\text { countries }\end{array}$ \\
\hline $\begin{array}{l}\text { Dr. A. Q. } \\
\text { (university } \\
\text { professor of } \\
\text { Islamic creed/ } \\
\text { Islamic preacher) }\end{array}$ & ० & $\begin{array}{l}\text { spreading } \\
\text { corruption and } \\
\text { crime }\end{array}$ & & & & & & o & $\begin{array}{l}\text { to } \\
\text { consolidate } \\
\text { the family as } \\
\text { a foundation } \\
\text { that is based }\end{array}$ \\
\hline
\end{tabular}


on love,

tolerance

and good

values away

from vice

and

\author{
F. H. (newspaper \\ columnist)
}

Dr. Abd. Q
(doctor of
bacterial diseases
with Islamic
religious
affiliation)

observers
- scandals

- decadence

o immoral and abnormal ideas, perverted from our values standards

- a swamp of ethical scandals

o crime

○ forbidden serious and destructive practices

- a heinous crime against the religion and society and generation

- exotic ideas on our society and the celestial religions o the trash of

incidental and

imported

ideas alien to

our society

$\circ$ organised

groups $\circ$ protectin

g it... by

the law

... via a

cover-up

private

associati

on

○ unknown

quarters o it received a sharp attack

from observers

Table 1 illustrates that there is some discrepancy of the type of discourse producers who collectively produced and shaped this anti-homosexuality and anti-homosexuals public discourse in Jordan in the aftermath of the LGBTQIA meeting. One can perceive also that under this angle, the producers of this discourse belong to different social backgrounds but they characteristically adopt an Islamic religious connexion by which they ground their stance. Herein, and as perceived in the table above, homosexuality is negatively portrayed and depicted as an outcome of efforts to westernise society. It is not regarded inherent within culture, and it is not perceived as sawey (a normal) behaviour. The argument here is intensified as homosexuality is criminalised by the discourse producers, and they express their denunciation of homosexuals by avoiding referring to them by their known neutral labels methley (homosexual or gay). Instead, the discourse producers systematically address homosexuals and gays using derogatory terms or connotations (e.g. corrupted models, advocates of vice and obscenity, suspicious, perversion, trash). This strategy marginalises homosexuals and gays by rescinding their names which impersonate their distinguished identity as a minority group. The marginalisation of homosexuals continues by the use of metaphorical language (e.g., as a stab and crime) to negatively evaluate homosexuality and to present homosexuals and gays as aliens to the heritage and culture of Jordan, and that they do not belong to it; especially since they breached the law by their reliance on western support.

Remarkably, and apart of condemning homosexuality and LGBTQIA community, the data revels that this antihomosexuality and anti-homosexuals discourse lacks any substantial argument. For instance, the discourse producers do not overtly foreground and address the official body or authority responsible of dealing with this issue. Still, in few instance, the discourse producers hint to a sort of societal and communal responsibility. It is found more fruitful and preferable to resort to substantial measures on the ground, and sometimes, to encourage the use of force against homosexuals and their activities. Hence, we find lexes which call for radical and forceful measures which aim eradicate this phenomenon before it spreads']; in the discourse producer's words, wa'd (to nip in the bud; lit. burry anew-born enfant in a grave) and by Hazm (firmness) and by quwa (strength). Furthermore, the anti-homosexuality and antihomosexual discourse producers argue that their calls aim to protect the victimised 'moral values of society' and to emphasise the Islamic roots and heritage of society.

\subsection{The (Islamic) Religious Argument}

The majority of the advocates of the anti-homosexuality and anti-homosexuals discourse in Jordan ground their argument on Islamic Shari'a (law and jurisprudence) that explicitly prohibits homosexuality. Islam teaches that homosexuality is a vile form of fornication, and it is punishable by death. This stance is detailed in the Qur'an by an account based on the story of the people of Prophet Lot (Sodom) as it says "...For ye practice your lusts on men in preference to women: ye are indeed a people transgressing beyond bounds.... And we rained down on them a shower (of brimstone)" (7:80-84). Herein, the "rain of stones" on the town is interpreted as that homosexuals should be stoned to 
death because of their vile deeds, since no other reason is given for God to cast such an overwhelming punishment on the entire people of Prophet Lot. In addition, it is found in the Prophet Muhammed's tradition that he says "Whoever you find doing the action of the people of Lot, execute the one who does it and the one to whom it is done." (Sunan Abu Dawud, Saying no. 4462). This religious argument is ubiquitous in the data collects, and Table 2 below illustrates:

Table 2. Representative examples of the lexical choice of processes and themes based on the (Islamic) religious argument

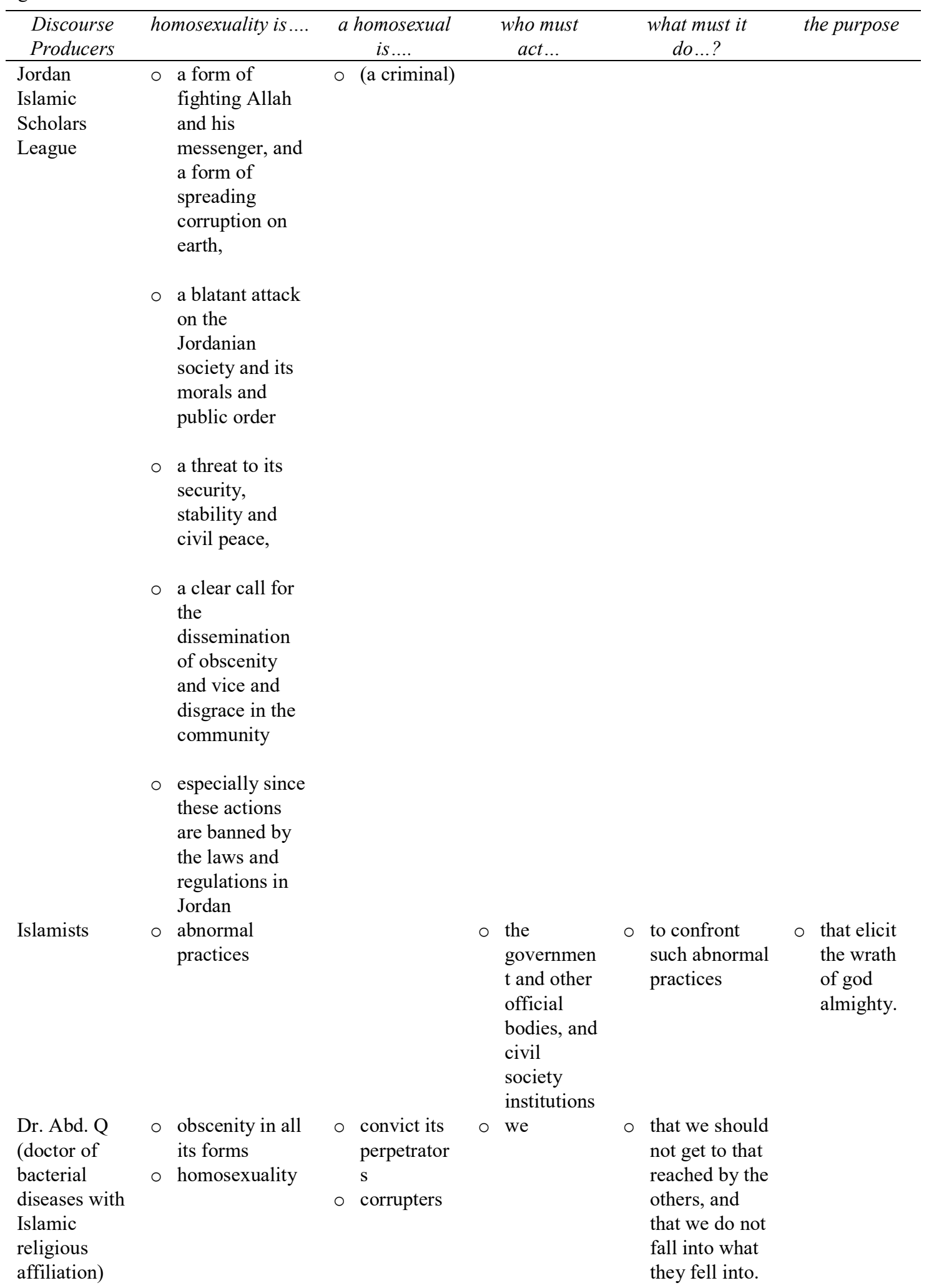


T. Abu.R. (a
Lawyer/with
Islamic
religious
affiliation)

O. Sh.

(Islamic

preacher and

researcher)
O a crime by the Jordanian law

o a violation of the constitution of Jordan

○ perversion
○ Jordanians

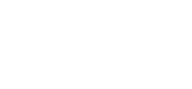

Abd. T. (a

linguist with a $\mathrm{PhD}$ )

Observers
- contrary to the principles of Islamic law, and the customs and traditions of Jordanian society.
- Muslim imams and Christian clergy
- we should be the most vigilant people on the planet

$\begin{array}{ll}\text { to convey the } & \circ \text { the aim is } \\ \text { message that } & \text { the } \\ \text { god created us } & \text { reconstruc } \\ \text { for mating and } & \text { tion of } \\ \text { reproduction } & \text { earth }\end{array}$
the aim is the earth
○ we might

be the

only

country in which the history of mankind witnessed the lord's punishmen $t$ for this crime, when god almighty annihilate $d$ the sodomites because of their insistence on sexual perversion and their refusal to repent

The (Islamic) religious argument is based on that the majority of Jordanian populations are Sunni Muslims. Accordingly, the constant reliance on the religious argument in condemning homosexuality and homosexuals stems from Islamic Shari'a which prohibits sexual relationships outside heterosexual marriage. In addition, it strictly forbids homosexuality and dictates severe penalty on those found guilty of committing such obscenity (faHesha). The table above (2) demonstrates that the advocates of the (Islamic) religious argument are characterised by their individual, rather than institutional, affiliation upon which they ground their argument. Even the Jordan Islamic Scholars League who adopts this argument, as other Islamist writers do, addresses the issue from their own distinctive non-official viewpoint.

We notice also from the table above (no. 2) that homosexuality is ideologically recognised as a 'corrupt' act of sodomy. This reference aims to accentuate that homosexuality is perceived as mumarasaat shathah (abnormal practices) and a sort of shuthuuth gensi (sexual perversion). Hence, homosexuality is likened to acts of sodomy, and it should be criminalised by society and law because it is against Islamic (and other celestial) laws and Islamic Shari'a is the main source of legislation in Jordan as the Constitution decrees. Under this argument, we see that there is no explicit reference to homosexuals and gays as they are not recognised as a component of society or a minority group. Instead, a gay person is negatively perceived as an 'abnormal' person or a 'pervert' and a 'criminal' and a 'corrupter' that should be persecuted and fought. As an organised community, homosexuals and gays are considered a threat to society because they are mufsedeen (corrupters), which entails that they endeavour on spreading their fasaad (corruption) in society. Such stance aims to marginalise the LGBTQIA community in Jordan by considering them aliens to the Jordanian society. 
Table no. 2 illustrates also that the proponent of this argument are more explicit in calling the pertinent official bodies and authorities to take an action and hound the LGBTQIA community and prohibit their events and activities. Although the manner by which the action to be taken is not explicitly stated, there is an understood orientation toward using peaceful and non-violent methods when they call 'Muslim Imams (preachers) and Christian clergy' to explain to homosexuals and gays that the massage that 'God created us for mating and reproduction'. Thus, this argument accentuates that it does not adopt Islamic doctrine and ideology as its basis; instead, it refers to 'Christian clergy' to stand 'in their side' in fighting this phenomenon and its practitioners. This stance aims to convey a message of unification to all components of Jordanian society in condemning the meeting, its goals, and its organisers, and their sexual orientation. On the basis of what is listed under 'the purpose' column in Table no. 2 above, the goal of the (Islamic) religious argument is to emphasise the universal threat that lurks around society because of the open activities of the LGBTQIA community in Jordan. This threat is mostly presented in terms of religious basis; thus we have reference to the idea that such activities bring ghaDab Allah (the wrath of god) on society as it is presented in the story of the people of Lot (Sodom and Gomorrah) and their overwhelming destruction for their obscenity. The theme of the overwhelming punishment - that spares no one - aims to unify all individuals and institutions of society especially those who are indifferent and silent about the spread of this phenomenon.

\subsection{Protecting and Reinforcing Law and Order}

The angle of law and order was present in the argument of anti-homosexuality and anti-homosexuals discourse producers. The argument is that the event organised by the LGBTQIA community in May 2015, and which was attended by the US Ambassador, must be categorised unlawful under the provisions of the Public Meetings Law in Jordan of 2004 and its amendments in 2011. Under this law, all public meetings and events should obtain 'the approval of the local administrative governor', and the LGBTQIA meeting did not meet this requirement. However, this argument was not central in the public debate in the aftermath of the event; instead, most the anti-homosexuality and anti-homosexuals discourse makers in Jordan marginalised this incidence and focused their attention on criminalizing homosexuality as a demeanour and LGBTQIA community as committers of this condemned demeanour. This can be plainly perceived in Table 3 below:

Table 3. Representative examples of the lexical choice of processes and themes based on the argument of protecting law and order

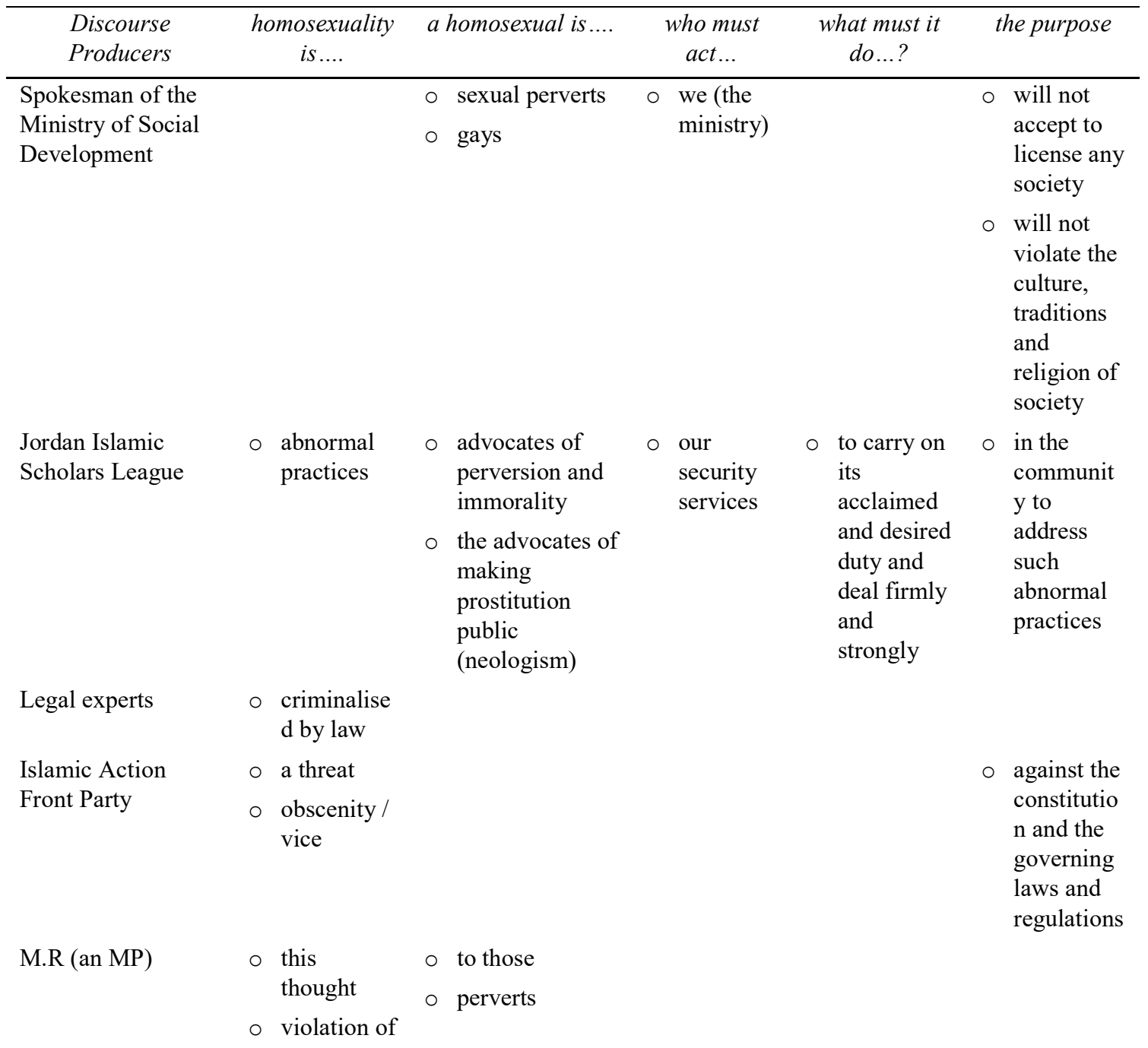


Islamic

values and

the

constitutio

$\mathrm{n}$ of the

state

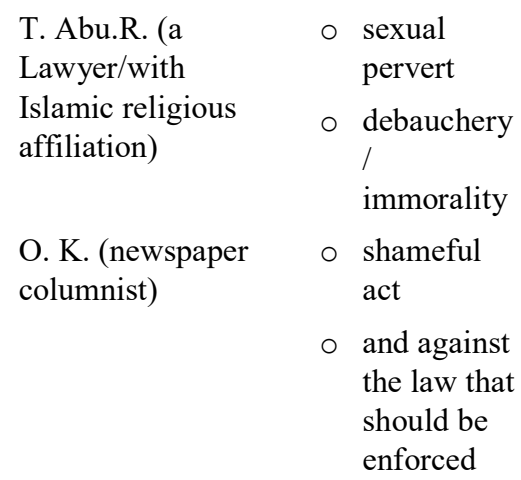

Dr. A. Q.

(university

professor of Islamic

creed/ Islamic

preacher)
- advocates of perversion and prostitution

- extremists abusing the law in Jordan

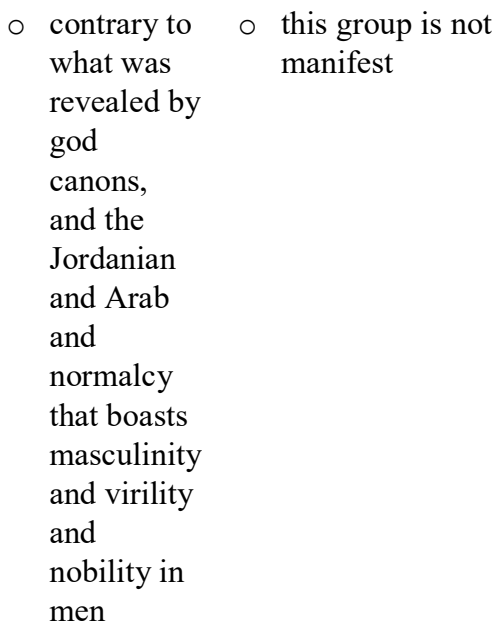

$\begin{array}{ll}\begin{array}{l}\text { be tried } \\ \text { and }\end{array} & \circ \begin{array}{l}\text { because } \\ \text { they are }\end{array} \\ \text { prosecuted } & \text { calling for } \\ & \text { the } \\ & \text { destruction } \\ & \text { of the } \\ & \text { communit } \\ & \text { y value } \\ & \text { system }\end{array}$
$\circ$ disease
T. Kh. (writer)
$\circ$ group
$\circ$ afflicted by this attribute

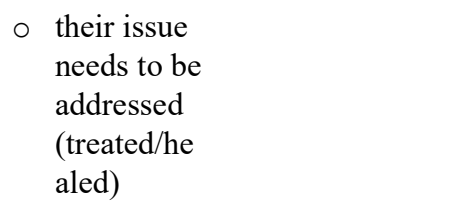

Table 3 above illustrates how the advocates of this argument did not refer to an overt article in the Jordanian penal codes that criminalises homosexuality per se despite admitting that homosexuality is not officially or publicly approved. This dilemma has been shyly addressed by few legislators and writers, and the government turns a deaf ear to the demands to criminalise homosexuality in Jordan. One can attribute this official stance to the observation, manifested in the table (no. 3) above, that in match with the (Islamic) religion argument, the majority of the advocates of the argument of protecting law and order are individuals and not institutions. However, few social and political, but unofficial, bodies have overtly addressed the necessity of putting legislations that prohibit homosexuality in Jordan (i.e. the Islamic Action Front Party, Jordan Islamic Scholars League, and an MP). By such legislations, it is aimed that LGBTQIA community meetings and activities shall be criminalised by law. The proponent of this argument do not regard homosexuality acceptable, and that it should not be defined in terms of Horeya shakhSeyah (personal freedom) or acknowledged by civil rights. Otherwise, homosexuality, again perceived as 'abnormal practices', should be tujarram (criminalised) because it is considered a tahdeed (a threat) and intihaak (a violation) of the constitution of the state because it is against Islamic Shari'a. 
Table no. 3 illustrates also that there is a significant variation in referring to homosexuality by different terms which involve negative connotations. Homosexuality is perceived as fujuur (debauchery / immorality) and fe3l musheen (a shameful act) and metaphorised as daa' (a disease). Accordingly, a homosexual, or a gay, is considered mujrem (a criminal) who must be brought to justice and persecuted and punished, and this applies also to those who attended the infamous LGBTQIA meeting and organised it. In addition to that, the producers of this discourse followed the advocates of the previous anti-homosexuality and anti-homosexuals' arguments in referring to homosexuals, or gays, using terms with negative connotations. Herein, members of the LGBTQIA community are regarded shawaath or shatheen gensyan (sexual perverts), do3atu alratheela (advocates of perversion and immorality) and creatively portrayed using the neologism ta3heer to mean the 'advocates of making prostitution public'. In addition, the LGBTQIA's conduct in organising secret and mashbuuh (suspicious) meetings and events is likened to that of mutaTarfuun (extremists). Remarkably, only one governmental body, represented by the Spokesman of the Ministry of Social Development, has followed the public mainstream and commented on homosexuals, and not homosexuality, when he referred to them as 'sexual perverts' and 'gays'.

From the above argument and illustration, we can perceive that homosexuals in Jordan are marginalised by being criminalised since they make fe'a mubtalia (an afflicted group) by this demeanour. The argument of marginalisation and criminalisation is reinforced by regarding homosexuals breaking an undictated code of conduct, or a convention, that prohibits addressing the question of homosexuality and LGBTQIA's rights publicly in Jordan. This explains the pertinent paucity and elusiveness with regard of the official body and authority whose responsibility is to reinforce law and order against LGBTQIA community in Jordan and their activities. Although there is no explicit mention to the body or authority on which relies the responsibility of reinforcing law on LGBTQIA in Jordan, there are a few references to alajheza alamneya (the security services) and their role in executing role and order. Accordingly, few advocates of this argument still recommend treating homosexuality by reinforcing law and violent actions against homosexuals and their activities despite of their realisation of the legislative problem concerning the legal status of homosexuals and their activities.

\subsection{The Argument of (Homo)Sexually-Transmitted Diseases}

This argument is advocated by a small number of the anti-homosexuality and anti-homosexuals discourse producers. Under this argument lies a proposition that if homosexuality is legitimized or becomes widespread then there is a physical threat to society caused by sexually-transmitted diseases like AIDS. Most advocates of this argument are medical doctors who provided a technical account on the relationship between unsafe and uncontrolled sexual relationships, which homosexuals are believed to engage in, and the transmission of alamraaD algenseya (sexuallytransmitted diseases) among those who are engaged in homosexual practices. However, this argument is presented in brief and insufficient elaboration as Table 4 below illustrates:

Table 4. Representative examples of the lexical choice of processes and themes based on the argument of (homo) sexually-transmitted diseases

\begin{tabular}{|c|c|c|c|c|c|c|c|}
\hline $\begin{array}{l}\text { Discourse } \\
\text { Producers }\end{array}$ & & $\begin{array}{c}\text { homosexuality } \\
\text { is.... } \\
\end{array}$ & & $\begin{array}{c}\text { homosexual } \\
\text { is.... }\end{array}$ & $\begin{array}{c}\text { who must } \\
\text { act... }\end{array}$ & $\begin{array}{c}\text { what must it } \\
\text { do...? }\end{array}$ & the purpose \\
\hline $\begin{array}{l}\text { Dr. Abd. Q (doctor of } \\
\text { bacterial diseases } \\
\text { with Islamic religious } \\
\text { affiliation) }\end{array}$ & 0 & $\begin{array}{l}\text { sexual } \\
\text { perversion }\end{array}$ & 0 & $\begin{array}{l}\text { gays / } \\
\text { homosexuals } \\
\text { sexual } \\
\text { perverts }\end{array}$ & & $\begin{array}{l}0 \\
0 \\
0\end{array}$ & $\begin{array}{l}70 \% \text { of the } \\
\text { people infected } \\
\text { with aids was } \\
\text { because of } \\
\text { homosexuality } \\
\text { (i.e. among } \\
\text { gays) } \\
\text { the main } \\
\text { reason for this } \\
\text { alarming } \\
\text { outbreak is } \\
\text { homosexuality }\end{array}$ \\
\hline $\begin{array}{l}\text { Dr. M. H. (university } \\
\text { professor/newspaper } \\
\text { columnist)) }\end{array}$ & O & $\begin{array}{l}\text { the man } \\
\text { marries a man } \\
\text { the women } \\
\text { marry women }\end{array}$ & & & & ○ & $\begin{array}{l}\text { abnormal cases } \\
\text { of incongruity } \\
\text { and corruption } \\
\text { take place, in } \\
\text { addition to } \\
\text { sexual, } \\
\text { organic, social } \\
\text { and moral } \\
\text { diseases } \\
\text { appear in } \\
\text { normal } \\
\text { communities! }\end{array}$ \\
\hline
\end{tabular}


O. Sh. (Islamic preacher and researcher)

$\circ$ the vice of $\bigcirc$ perpetrators
sexual
perversion
$\circ$ homosexuality

(perversion)

0 incurable

diseases, the

most serious is

aids

o the utter

destruction of

human race

The table 4 above illustrates that despite the scientific proposition of this argument, the discourse producers are still bound to the public opinion that regards homosexuality as an 'abnormal practice' and an example of 'sexual perversion'. For instance, the proponent of this argument still call homosexuality using derogatory terms (i.e. sexual perversion). A moderate account regards homosexuality through a socially-oriented perspective that regards a 'samesex marriage' or 'the man marries a man; the women marry women'. This last perspective shows how the discourse producer accepts that a homosexual believes in the social order and its practices like marriage. One may wonder if this proposition implies also that the LGBTQIA community believes in social commitment (like living in matrimony) and according to their 'abnormal' manner. On the other hand, the advocates of this argument accentuate that homosexuals are not DaHaaya (victims) of their sexual orientation and disease which could inflict them. Instead, as homosexuality is regarded as a 'pervert' practice, its practitioners are regarded just murtakbeen (perpetrators) and not DaHaaya (victims). In addition, the advocates of the argument of (homo)sexually-transmitted diseases do not mention what the official bodies and authorities, or even people, must do. Nevertheless, the outcome of doing nothing is implicitly highlighted by the elaborated explanation of the sexually-transmitted deceases as the product of homosexuality; not unprotected heterosexual relationships. This interpretation emphasises the superiority of heterosexuality over homosexuality as a factor of assuring the continuity of the life of mankind by mating and reproduction. On the one hand, it warns that the spread of homosexuality will inevitably lead to the annihilation of mankind because of the decrease in reproduction rates and the spread of incurable diseases. Here, the discourse producers resort to arouse the idea of universal threat. Here, the idea is engulfed with a scientific, rather than religious account like that of the 'wrath of God' and the 'overwhelming punishment'. Accordingly, it can be argued that the argument of (homo)sexually-transmitted diseases supports the religious dimension and reemphasises the common responsibility of all components of society in taking preventive measures against the spread of homosexuality in society.

\subsection{The Calls of Pro-Homosexuality and Pro-Homosexuals and LGBTQIA's Rights Activists}

It defies logic and reason to postulate that the Jordanian public discourse on homosexuality is entirely against homosexuality and the rights of LGBTQIA community. The data in hand shows different opinions and arguments which regard anti-homosexuality and anti-homosexuals discourse as a realisation of prejudiced and unjustifiable homophobia. This stance accentuates the significance of tackling the issue of homosexuality and homosexuals in Jordan from an objective and unbiased standpoint which perceives homosexuality as a natural phenomenon found in all cultures and through history. This argument is discursively presented in our data by different sorts of discourse producers and using different sorts of lexes as Table 5 below illustrates:

Table 5. Representative examples of the lexical choice of processes and themes based on the calls of homosexuals and pro-homosexuals and LGBTQIA rights activists

\begin{tabular}{|c|c|c|c|c|c|}
\hline $\begin{array}{l}\text { Discourse } \\
\text { Producers }\end{array}$ & $\begin{array}{c}\text { homosexuality } \\
\text { is.... }\end{array}$ & $\begin{array}{c}\text { a homosexual } \\
\text { is .... }\end{array}$ & $\begin{array}{c}\text { who must } \\
\text { act... }\end{array}$ & $\begin{array}{c}\text { what must it } \\
\text { do...? }\end{array}$ & the purpose \\
\hline $\begin{array}{l}\text { My.Kali } \\
\text { Magazine }\end{array}$ & $\begin{array}{l}\text { homosexuality } \\
\text { and sexuality } \\
\text { 'gensanyeah' } \\
\text { and gender } \\
\text { 'ginder' }\end{array}$ & & & & \\
\hline $\begin{array}{l}\text { A legal } \\
\text { researcher }\end{array}$ & & $\begin{array}{l}\text { gay, } \\
\text { transgender }\end{array}$ & & & \\
\hline $\begin{array}{l}\text { A Jordanian } \\
\text { based in } \\
\text { Amman, called } \\
\text { (H. K.) }\end{array}$ & & $\circ$ ' gays & & $\begin{array}{l}\text { more of } \\
\text { these events } \\
\text { will be held } \\
\text { in Jordan }\end{array}$ & $\begin{array}{l}\text { to identify gay } \\
\text { rights and defend } \\
\text { them }\end{array}$ \\
\hline $\begin{array}{l}\text { a member of the } \\
\text { Jordanian }\end{array}$ & & $\begin{array}{l}\text { gay, } \\
\text { transgender }\end{array}$ & & & \\
\hline $\begin{array}{l}\text { Assembly to } \\
\text { demand the gays } \\
\text { rights }\end{array}$ & & , & & & \\
\hline $\begin{array}{l}\text { A page entitled } \\
\text { LGBTQIA } \\
\text { Awareness in } \\
\text { Jordan }\end{array}$ & o homosexuality & & & & \\
\hline US Ambassador & & o human & & & $\circ$ gay rights are \\
\hline
\end{tabular}


Gays

Dana (21 years)

Transgender

and activist
○ transgender

○ citizens

Jordan

(H. K.) a gay-

rights activist

The so called

Haifa (male)

A gay page

based in Jordan

0 his

homosexual

$\circ$ gays

orientation

$\circ$ gays
○ to hold seminars and

dialogues

through

which views

are

exchanged

0 the biggest challenge that transgender members of the Jordanian society suffer from today is that the government of Jordan does not recognize them.

0 if you are a transgender you cannot change your name, id, driver's license, or passport

o realize their full rights as citizens to live with dignity in this country

$\circ$ he and gays

○ everyone like him

- we have come to a dialogue and a common language

o their battle against homophobia in Jordan will be retained
- breaking the barrier of fear to identify their rights in the Jordanian society,
- a Jordanian gay
- making change

- raise awareness

o protect gays from social anxiety disorder

o homosexuality is

- protect society from isolating the total homosexual community challenge the social standards, access to a safe Jordan for all society'

- each Jordanian gay enjoys the rights enjoyed by any ordinary Jordanian not a choice

o in which we can members of

\section{society called}

Hasan

participants

Table 5 illustrates how homosexuality is perceived under this argument as a natural outcome of people's awareness of their own self and identity, and that the aim of LGBTQIA rights activists is to spread this awareness in society. Although Jordan did not witness any violence incidents associated to homophobia, the producers of the prohomosexuality and pro-homosexuals discourse identify themselves as 'gays', and in most cases, they remained 
anonymous or used alias (e.g. 'Dana, 21 years'; 'the so called Haifa (male)') for their own safety concerns. In addition, few pro-homosexuality and LGBTQIA rights activists emphasise their heterosexual orientation within this discourse, and they defend the rights of LGBTQIA groups in accordance with their humanitarian beliefs and duties. However, they prefer keeping their identity anonymous too.

Under this argument, homosexuality is perceived a natural muyuul (orientation and inclination) that should not reflect any negative prejudice, connotations, or association with perversion and corruption of personality or morality. Thus, homosexuals are called with their accustomed name methleyeen (gays), and some of them emphasised their national identity as methley orduni (a Jordanian citizen). In addition, an in-group term is used by LGBTQIA community is mutaHawel gensian (transgender) that has never been used by the advocates of anti-homosexuals and antihomosexuality. The advocates of this argument emphasise that it is the LGBTQIA group's responsibility to obtain their wanted recognition; hence, no authority or institution were explicitly addressed to support their calls. This is mostly perceived discursively by their constant use of the inclusive plural personal pronoun (we) that aims to unify all members of LGBTQIA community in Jordan to fulfil their main dream. Additionally, they emphasise that their dream of obtaining social and official i3teraaf (recognition) can be attained by resorting to non-violent strategies to nashralwa3y (raise awareness) of the LGBTQIA's rights in Jordan. This is mostly manifested through their discursive practice of using terms which refer to the voice of reason and rationality (e.g. seminars, dialogues, views, events, to talk, raise awareness, a common language). Nevertheless, a few voices called for taking more radical actions, that may trigger a violent reaction, such as that of 'the so-called Haifa', who demanded his colleagues to 'order a march or a protest in downtown Amman' or to request 'international support'. Such voices are still quiet, and nobody listens to, as one could easily predict the consequences of such actions on the safety of the members LGBTQIA community. What is remarkable here, and as it is perceived in the table (no. 5), is that pro-homosexuals and LGBTQIA rights activists discourse emphasises the LGBTQIA's unquestionable affiliation and loyalty to the nation, and that they demand recognition from their society not from the outside as it is allegedly contended by the anti-homosexuality and antihomosexuals' rallies. Herein, the discourse producers here reject their marginalisation and criminalisation, and they stress that their main concern is not to fight society and its norms but to fight homophobia within the Jordanian society.

\subsection{The Homosexuals' Own Self-Representation}

This angle investigates what members of LGBTQIA community say about their cause in seeking to "squeezing identity out of the box" and "raise awareness of the social and economic challenges facing the LGBTQIA community" in Jordan. Similar to the situation of non-homosexual LGBTQIA rights activists, the LGBTQIA community's discourse is presented to Jordanian public indirectly by homosexuals who are active online using their professional titles or alias or through media outlets (like My.Kali Magazine). Herein, the argument of the LGBTQIA community regarding the quest for recognition is illustrated in Table 6 below:

Table 6. Representative examples of the lexical choice of processes and themes based on the homosexuals' own self-representation

\begin{tabular}{|c|c|c|c|c|c|c|c|c|}
\hline $\begin{array}{l}\text { Discourse } \\
\text { Producers }\end{array}$ & $\begin{array}{c}\text { homosexuality } \\
\text { is.... }\end{array}$ & & $\begin{array}{c}\text { a homosexual } \\
\text { is.... }\end{array}$ & $\begin{array}{c}\text { who must } \\
\text { act... }\end{array}$ & & $\begin{array}{l}\text { hat must it } \\
\text { do...? }\end{array}$ & & the purpose \\
\hline $\begin{array}{l}\text { The magazine } \\
\text { (My.Kali) }\end{array}$ & & & $\begin{array}{l}\text { transgenes } \\
\text { as citizens }\end{array}$ & & & $\begin{array}{l}\text { the } \\
\text { transgender } \\
\text { community } \\
\text { in Jordan } \\
\text { needs to } \\
\text { have more } \\
\text { support }\end{array}$ & 0 & $\begin{array}{l}\text { and must } \\
\text { achieve their } \\
\text { full rights as } \\
\text { dignified } \\
\text { citizens of this } \\
\text { country. }\end{array}$ \\
\hline $\begin{array}{l}\text { The magazine } \\
\text { (My.Kali) }\end{array}$ & & ○ & $\begin{array}{l}\text { a small crowd } \\
\text { full of hope }\end{array}$ & & & & o & $\begin{array}{l}\text { for a better and } \\
\text { safer future for } \\
\text { the } \\
\text { LGBTQIAI } \\
\text { community in } \\
\text { Jordan }\end{array}$ \\
\hline $\begin{array}{l}\text { The magazine } \\
\text { (My.Kali) }\end{array}$ & & & activist & & o & $\begin{array}{l}\text { we have to } \\
\text { reach to a } \\
\text { dialogue } \\
\text { and a } \\
\text { common } \\
\text { language in } \\
\text { which we } \\
\text { can } \\
\text { challenge } \\
\text { societal } \\
\text { norms, and } \\
\text { achieve a }\end{array}$ & & \\
\hline
\end{tabular}


safe Jordan

for all

members

of its

society

$\begin{array}{lll}\begin{array}{l}\text { Owner of a } \\ \text { popular cafe in } \\ \text { the capital, }\end{array} & \begin{array}{l}\text { my } \\ \text { homosexuality }\end{array} & \begin{array}{l}\text { acknowledged } \\ \text { activists who } \\ \text { declare their } \\ \text { Amman }\end{array} \\ & \begin{array}{l}\text { membership } \\ \text { in the } \\ \text { assembly }\end{array} \\ & \end{array}$

Jordan

Haifa'a of

$\circ$ his

orientations

○ human

Jordan

(inclinations)
○ gays

\author{
breat
}

barrier of

fear and go

out to the

public

o to live

according

to his

inclinations

and not as

others want !!
- face many challenges

○ attacks, which he described as reactionary and not appropriate to the present, stressing a man has the right to live according to his inclinations and not according to what others want!!

Table 6 above reveals that the LGBTQIA community in Jordan does not scrutinise how homosexuality is defined as the LGBTQIA rights activists do. Instead, we see a constant reference to their muyuul (orientation and inclination) without defining the nature of this orientation and the reasons behind it. When it comes to their own self-identity, LGBTQIA members define themselves as normal humans and citizens who seek the recognition of their 'small' community as a minority group. The frequent use of the phrase mujtama 3 methley (a homosexual community) reflects their emphasis on regarding themselves as a minority group that seeks recognition and protection. For the moment, it seems that the LGBTQIA community is not seeking the official recognition of authorities and institutions; hence we find no explicit reference in the table above to anyone outside the LGBTQIA community reacting to their demands. However, their demands and the goals are explicitly foregrounded and presented to the LGBTQIA community and the Jordanian society.

For the LGBTQIA community, their current status in Jordan is represented as bursting with taHadeyaat (challenges), and that the society's prejudiced idea about them are raj3eyah (reactionary and obsolete). Naturally, such a negative position can be understood by society as an attack on traditions and values which stem from Islamic religious background. However, the LGBTQIA community puts into public a strong and patriotic argument that rejects any endeavour to marginalise or alienate them as complete Jordanian citizens; and by underlining that, they want to obtain their rights in Jordan and live peacefully in society. Remarkably, most LGBTQIA calls do not overtly seek western support, and they deny reliance on it to exert international pressure on the Jordanian governments to gain recognition. Hence, they do not explicitly refer in their argument to the US Ambassador attendance of their meeting.

\subsection{The Neutral Scientific Account and Representation.}

This last angle tackles the Jordanian public debate from another perspective that counters the pro-homosexuality and pro-homosexuals' argument, but it does not totally coincide with the anti-homosexuality and anti-homosexuals one. Unsurprisingly, this argument involves the smallest number of discourse producers as it shows a more objective and less categorical interpretation of homosexuals and homosexuality as pertinent phenomena in different societies and cultures. Nonetheless, the advocates of this argument follows the public mainstream in regarding homosexuality as an 'abnormal practice' or a 'behaviours beyond the habit', but they engulf it with the proposition that it is a medical problem that needs treatment or a deed that needs control. This proposition is illustrated through Table 7: 
Table 7. Representative examples of the lexical choice of processes and themes based on the neutral scientific account and representation.

\begin{tabular}{|c|c|c|c|c|c|c|c|c|}
\hline $\begin{array}{l}\text { Discourse } \\
\text { Producers }\end{array}$ & & $\begin{array}{c}\text { homosexuality } \\
\text { is.... }\end{array}$ & & $\begin{array}{l}\text { homosexual } \\
\text { is.... }\end{array}$ & $\begin{array}{c}\text { who must } \\
\text { act... }\end{array}$ & $\begin{array}{c}\text { what must it } \\
\text { do...? }\end{array}$ & & the purpose \\
\hline Penal Code & o & $\begin{array}{l}\text { abusive } \\
\text { actions and } \\
\text { conducts } \\
\text { corrupting } \\
\text { moral values }\end{array}$ & 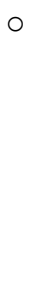 & $\begin{array}{l}\text { anyone } \\
\text { found guilty } \\
\text { of abusive } \\
\text { and } \\
\text { indecent } \\
\text { actions and } \\
\text { conducts }\end{array}$ & & & & \\
\hline N. (Lawyer) & & & ० & gay people & & & & \\
\hline $\begin{array}{l}\text { A legal } \\
\text { researcher }\end{array}$ & & & $\begin{array}{l}0 \\
0\end{array}$ & $\begin{array}{l}\text { membership } \\
\text { of the world } \\
\text { society for } \\
\text { the rights of } \\
\text { gay and } \\
\text { transgender } \\
\text { gays } \\
\text { transgenders }\end{array}$ & & & 0 & $\begin{array}{l}\text { it did not } \\
\text { specify its } \\
\text { position on } \\
\text { the } \\
\text { preservation } \\
\text { of human } \\
\text { dignity of } \\
\text { gays in } \\
\text { Jordan }\end{array}$ \\
\hline $\begin{array}{l}\text { Abd. T. (a } \\
\text { linguist with a } \\
\text { PhD) }\end{array}$ & $\begin{array}{l}\circ \\
0\end{array}$ & $\begin{array}{l}\text { (disease) } \\
\text { behaviours } \\
\text { beyond the } \\
\text { habit }\end{array}$ & ० & patient & $\begin{array}{ll}\circ & \begin{array}{l}\text { medical } \\
\text { doctors }\end{array} \\
\text { we } \\
\text { (society) }\end{array}$ & $\begin{array}{l}\text { adjust the } \\
\text { rate of } \\
\text { hormones to } \\
\text { be balanced } \\
\text { and } \\
\text { proportional } \\
\text { to the } \\
\text { normal } \\
\text { conditions } \\
\text { to look for } \\
\text { the } \\
\text { underlying } \\
\text { causes of } \\
\text { this issue } \\
\text { and try to } \\
\text { address } \\
\text { them }\end{array}$ & & \\
\hline unknown & & & & $\begin{array}{l}\text { gays } \\
\text { humans }\end{array}$ & & & ० & $\begin{array}{l}\text { preservation } \\
\text { of human } \\
\text { dignity for } \\
\text { gays }\end{array}$ \\
\hline unknown & o & homosexuality & & & & & & \\
\hline
\end{tabular}

The discourse producers of the neutral account and representation are found to be regularly academics or legal experts with no Islamic religious affiliation. In this regard, a homosexual person is regarded as mareeD (a patient) who needs 3elaaj (treatment). Nevertheless, few medical doctors addressed the issue and they oriented their orientation to the sexually-transmitted diseases rather than to the nature of homosexuality and homosexuals. The advocates of this argument accept that homosexuality is a problem and its solution requires collective responsibility from society. As academics, and medical doctors, they admit that treating homosexuals is their responsibility, but to make them return to the 'normal' life is the responsibility of the state and society. This is presented through their use of the inclusive plural personal pronoun (we) by which they call society to unify its effort and understand the needs of homosexuals to be treated and cured rather than marginalised and criminalised. Hence, this argument perceives the penal code supportive in treating homosexuality in Jordan in the same manner it aims to treat other abusive behaviours like drug addiction. Accordingly, society should provide treatment to homosexuals, and this involves physical treatment 'adjust the rate of hormones to be balanced and proportional to the normal conditions' or using more educational and informative methods 'To look for the underlying causes of this issue and try to address them'.

Although they do not refer to homosexuality explicitly, hence does not criminalise it, many advocates of the neutral and scientific account still believe that once it becomes public, homosexuality is better being handled under the labels of 'abusive and indecent actions' and conducts or actions which lead to 'corrupting moral values'. Still, the neutral and 
scientific account and representation takes into consideration the necessity of protecting the humanity of the homosexual person, and it does not seek their criminalisation; rather, it calls to their containment; and this represents the voice of the minority in Jordan.

\section{Conclusion}

The analysis provided above demonstrates few aspects of the question of homosexuality and homosexuals and homophobia in Jordan from a discursive perspective. This public discourse is mostly motivated by the (Islamic) religious ideology and the deeply-rooted socio-cultural beliefs and some folk ideas which all together formulate a unified and comprehensive ideology that aims to marginalise and criminalise LGBTQIA community in Jordan. Moreover, members of LGBTQIA community are perceived inferior and unwelcomed in society because they are not normal heterosexual citizens like the rest. As the ultimate goal of LGBTQIA and pro-homosexuality debate would be to construct a discourse of a new gender-identity category and under which Jordanian homosexuals can be officially categorised, there is a conformist argument in Jordanian public discourse that regards the question of homosexuality a prohibited area of official discussion by the government. This position resulted serious problems regarding the identification of homosexuality and homosexuals and the way they must be 'officially' labelled. For instance, the data in hand reveals that the Jordanian public tends to refer to homosexuals as almethleyeen and gays as al-shathawaath gensian (the sexually perverts) in their public writing. Remarkably, the Jordanian public discourse on homosexuality is bursting with the assumptions and beliefs that the LGBTQIA communities are enemies and conspirators who work as members of organised-crime groups; especially if we take into account the context of this discourse which propagated in the aftermath of the LGBTQIA meeting in Amman. However, this discourse fails to foreground and address substantial measure to dealing with this issue. Despite of the few instances where the discourse producers hinted that homosexuals are the responsibility of the entire society, the predominant mainstream opts to a physical and strong radical reaction, and sometimes encouraging the use of force against homosexuals and their activities. This stance is supported via the religious, and scientific, arguments which warn against the 'overwhelming punishment' and 'universal threat' once society accepts homosexuality and homosexuals. Accordingly, homosexuals are understood to be better dealt with by force; they should be stoned to death because of their vile deeds least God to cast an overwhelming punishment that could be materialised through epidemic and incurable deceases. This discursive practice is predominantly used by the majority of the discourse producers regardless of their social and ideological affiliations and backgrounds.

LGBTQIA community in Jordan are marginalised by being criminalised. This practice is materialised though the lexical choice of processes and themes which were assigned to homosexuals and homosexuality. They are labelled and categorised using negative and pejorative terms like 'abnormal' and 'perverts' and 'criminals' in order to construct a discourse that consolidate the conservative identity of society, and to prevent the circulation of any discourse that seeks the accreditation and acceptance of LGBTQIA members as a minority group in society. The severity of LGBTQIA activities is linked to the act of breaching the law and the Constitution of the Kingdom. Herein, producers of the discourse on the anti-homosexuality and anti-homosexuals emphasise that their argument does not adopt only Islamic doctrine and ideology as its basis; instead, it gains support from the unification of all the components of Jordanian society, regardless of their religions and beliefs, in condemning the homosexuality and homosexuals, their events, and their goals.

On the other hand, the data reveal that pro-homosexuals and LGBT rights activists discourse resorts to similar discursive strategies like those of their adversaries. This involves their emphasis that they are normal humans, and that the LGBTQIA's loyalty to their nation and society is unquestionable because they are 'citizens' and they want to 'live peacefully' in Jordan. They deny the allegations that they demand recognition by western support and from the outside. In this regard, their reliance in their argument on lexes which associated with rational and peaceful actions aims to denounce their marginalisation and criminalisation. Such lexical choice accentuates that their main concern is not to fight society and its norms and values but to 'raise the awareness' and fight homophobia in society. Within their inner circles, the LGBT community admits that their current status in Jordan is represented as bursting with taHadeyaat (challenges), and that the society's prejudiced idea about them are raj3eyah (reactionary and obsolete). Such a radical position is generally understood by society as a proof of the LGBTQIA 'suspicious agendas' against traditions and values, and this results in a stronger argument that favours their marginalisation and criminalisation.

\section{References}

Abu Dawud, Al-Imaam. Sunan Abu Dawud. [online]. A Collection of Prophet Muhammad's Sayings. Available online via: http://sunnah.com/abudawud

Barker, C. (2003). Cultural Studies: Theory and Practice. (2 $2^{\text {nd }}$ ed.). London: SAGE.

Burr, V. (1995). An Introduction to Social Constructionism. London: Routledge.

Cameron, D. (2001). Working with Spoken Discourse. London: SAGE.

Halliday, M. A. K. (1985). An Introduction to Functional Grammar. London: Edward Arnold.

Harris, J. Leiter, K. and Johnson, J. (1977). The Complete Reporter: Fundamentals of News Gathering, Writing and Editing. Macmillan Publishing Company: New York.

Johnston, Chris. (2015). Ireland becomes first country to legalise same-sex marriage by popular vote - live. The Guardian. Retrieved 23 May 2015 
Magid, Aaron. (2014). 'Little protection for gays in Jordan'. Al-Monitor. Accessed online via: http://www.almonitor.com/pulse/originals/2014/08/jordan-homosexuality-gay-lesbian-rights-lgbt-conservative.html\#ixzz3jxnbvtoT

Massad, J. A. (2007). Desiring Arabs. Chicago: The University of Chicago Press.

Pecheux, M. (1982). Language, Semantics and Ideology. Basingstoke: Macmillan.

Schmitt, A. and Sofer, J. (1992). Sexuality and Eroticism Among Males in Moslem Societies. Binghamton: Harrington Park Press.

UN Human Rights Committee. (1994). Toonen v. Australia, Communication No. 488/1992, U.N. Doc CCPR/C/50/D/488/1992. NYC: UN.

Weiner, Rachel. (2013). 'How Hillary Clinton evolved on gay marriage'. The Washington Post, accessed online on June 18, 2015 via https:/www.washingtonpost.com/blogs/the-fix/wp/2013/03/18/how-hillary-clinton-evolved-on-gaymarriage

\section{Notes:}

Note.1. LGBTQIA is derived from the initial letters of the words which collectively denote the different categories of homosexuals: Lesbian, Gay, Bisexual, Transgender, Queer, Intersex, and Asexual.

Note.2. At the time of the event, the Magazine was available online via https://mykalimag.com/; however, the website is no longer accessible, and the content of the Magazine is published on Facebook via https://www.facebook.com/mykalimag/.

Note.3. Read interviews with $\quad$ Dr. George $\quad$ Weinberg $\quad$ from 1997 via http://gaytoday.badpuppy.com/garchive/interview/020397in.htm .

Note.4. The identities of the individual discourse producers are masked with their initials throughout the article. Only institutions and organised bodies are identified. 